Agro-Science Journal of Tropical Agriculture, Food, Environment and Extension Volume 11 Number 1 January 2012 nn $10-15$

ISSN 1119-7455

\title{
SEED BED PREPARATION AND MULCHING METHODS FOR SUSTAINABLE TELFAIRIA PRODUCTION IN THE RAINFOREST AGROECOLOGY OF SOUTHEASTERN NIGERIA
}

\author{
Obiefuna J.C., IbeawuchI I.I., Okoli A.N. and Alagba R.A. \\ Federal University of Technology Owerri Nigeria \\ E-mail: juliusobiefuna@yahoo.com
}

\begin{abstract}
Seed bed preparation as the post land clearing operation, is crucial as a sustainable soil resource base for crop production in the rainforest agroecology. The study investigated the effects of four types of seedbed preparation (minimum tillage, harrowed flat, bed and ridge making) and three mulching methods (unmulched, surface and soil incorporation) using oil palm fruit fibre (fruit fibre) and multispecies thrash in owerri southeastern Nigeria. Owerri is located on latitude $5^{0} 27^{1} \mathrm{~N}$ and longitude $5^{0} 02^{1} \mathrm{E}$. The $4 \times 3$ factorial experiment was laid in a randomized complete block design with four replicates. Fruit fibre incorporation in beds and harrowed flat seed bed preparations significantly $(\mathrm{P}<0.05)$ enhanced the market quality of Telfairia occidentalis which was signified by production of heavy healthy leaves and large pods. It also improved the soil fertility at the end of the production cycle. Fruit fibre used either as a surface or incorporated mulch, was superior to thrash in weed suppression and yield of Telfairia. The unmulched seed beds, especially the ridge, produced poor Telfairia leaves and pods. Bed and harrowed flat seed bed preparations, when mulched (surface or incorporated) with fruit fibre, significantly $(\mathrm{P}<0.05)$ improved the returns on investment to the farmer.
\end{abstract}

Key words: Seed bed, mulching, Telfairia, rainforest.

\section{INTRODUCTION}

Vegetable production is a sustainable economic enterprise among rural and urban smallholder farmers especially women. In southeastern agroecology, vegetables feature prominently in mixed cropping systems and home gardens as secondary crops. In mixed crop production systems, vegetables share cultural practices (seed bed preparations, weeding, manuring etc) of the major crop. For example, in yam-based cropping system, the seed bed preparation (flat, mound, ridge etc) is mutually shared with the vegetables grown in the mixture. Telfairia (fluted pumpkin or ugu, Telfairia occidentalis) is a prominent, all season vegetable in home gardens (Akobundu et al., 1992) and remains the most dominant traditional port herb in Southeastern Nigerian crop mixtures where abundant wild and cultivated genotypes still exist (Akoroda, 1990).

However, Telfairia production and consumption has dispersed across ecologies and cultures following the environmental tolerance of Telfairia, its economic drive and positive contribution to good health (Aiyelaagbe, 2011). This root perennating vegetable is exclusively produced in polycultural production systems and marketed soley by rural, peri-urban and urban women. The broad leaves of Telfairia occidentalis, tender stems and immature seeds are highly marketable and widely consumed for good health (Schippers, 2000) especially for their beneficial effects on lipid profile, high antilipidaeonic effects on blood cholesterol, protection from associated cardiac problems, hypertension and diabetes (Akwuowo et al., 2000, Aletor et al., 2002 Uguru et al., 2011).

The management of the ultisol of the southeastern agroecology is crucial to the soil resource, its conservation and productivity of cultivated food crops and vegetables (Ojeniyi and Adekayode, 1999, Onweremadu et al., 2007). Seed bed preparation is a post land clearing soil disturbance to modify its structure for favourable root environment for enhanced plant growth, development and yield (Asoegwu, 1987). The efficiency of seed bed preparation is largely dependent on the soil types, crop and the available implement (Ojeniyi, 1990). Although vegetables require fine soil tilth, most farmers adopt minimal seed bed preparation because of resource constraints and cropping system culture (Akobundu et al., 1992). 
In traditional agriculture, the hoe is still and by far, the most widely used implement for seed bed preparations because the usually advocated mechanical tillage and herbicide use are soil and environmentally unfriendly, expensive and unaffordable by over $90 \%$ resource poor Nigerian farmers (Osuji and Babalola, 1982, Adekayide and Ojeniyi, 2002). Mulching with plant residues and synthetic polythenes have remarkably controlled weed (Osuji, 1990) enhanced soil biological health and fertility (Ohiri, 1995).

The Nigerian Telfairia growers, are skilled subsistence and commercial producers and marketers who lack access to land and credit, and more importantly to improved production package which will enable them sustain the production and supply of Telfairia products. Among the limitations, lack of basic information on sustainable agronomic production especially land preparation and mulch management package is major. This paper assessed the various seed bed preparation and mulch management methods with oil palm fruit fibre (fruit fibre) and multispecies thrash for sustainable Telfairia production in the ultisol of Southeastern agroecology of Nigeria.

\section{MATERIALS AND METHODS}

The study was conducted during the 2009 early cropping season at the Training and Research Farm of the Federal University of Technology, Owerri located $5^{0} 27^{1} \mathrm{~N}$ and $7^{0} 02^{1} \mathrm{E}$ at an elevation of $90.91 \mathrm{~m}$ in the rainforest agroecology of Southeastern Nigeria. The climate is unique. The heavy annual rainfall of over $2000 \mathrm{~mm}$, which spans over 8 months, usually from March to October, is bimodal with peaks in July and September followed by 4 months of dry season. The mean annual temperature $\left(30-32^{0} \mathrm{C}\right)$, relative humidity (79$89 \%$ ) are also high. The soil is a typical ultisol with characteristic acidic low fertility (Onweremadu, et al. 2007).

The experimental site, previously under two year Chromolena odarata fallow, was manually cleared and parked in windrows. Random soil samples, using soil augur at $0-$ $30.0 \mathrm{~cm}$ depth, were collected for analysis. The seed beds, each measuring $2.0 \times 8.0 \mathrm{~m}$, were manually prepared using spade. Thereafter, the oil palm (fruit fibre) or thrash mulch was either surface mulched or soil incorporated at $5 \mathrm{tha}^{-1}$ in appropriate seed beds. The 4 x 3 factorial experiment consisted of four seed bed preparations (minimum tillage, harrowed flat, bed and ridge) and three mulching methods (unmulched, surface and soil incorporation) using oil palm fruit fibre and multispecies thrash as test mulch. The experiment was laid out in a randomized complete block design with four replicates. The large Telfairia seeds $(3.0 \pm .05 \mathrm{~g})$ were spaced $2.0 \times 2.0 \mathrm{~m}$, planted two seeds per hill, and later thinned to one. Blanket poultry manure $\left(5 \mathrm{t} \mathrm{ha}^{-1}\right)$ was applied before seeding. Growth and yield data for Telfairia, post soil physico-chemical characteristics and bioindicators were collected, analyzed and reported.

\section{RESULTS}

The Telfairia seeds emerged within the same time (6-8 days) after planting irrespective of seed bed preparation or mulching methods for either the fruit fibre or thrash mulch (Table 1). However, the marketable yield (leaf and fruit) showed significant $(\mathrm{P}<0.05)$ yield variations. Telfairia grown on minimally tilled land produced the least marketable yields especially when unmulched. Yields of Telfairia planted on harrowed flat and bed doubled those planted in minimum tillage and ridges. Yields of Telfairia, mulched with fruit fibre, were superior to those mulched with thrash of the mulching method (surface or soil incorporation).

Seed bed preparation and mulching effectively suppressed weed growth, severity and disease incidence but improved soil health through increased populations of termites, earthworms, snails, millipedes etc (bioindicators) (Table 2). The harrowed flat, bed and ridge seed preparations mulched with palm fruit fibre were superior to seed bed preparations mulched with thrash in reduced pest incidence. Minimum tillage was least effective pest control. The biological indicators by species significantly increased in harrowed flat and bed seed preparations especially when mulched with fruit fibre. The unmulched minimum tillage and ridges were poor in biological life colonization.

The total variable cost, gross revenue, marginal cost and cost benefit ratio of the different seed bed preparations and mulching methods showed that minimum tillage was a cheap land preparation method especially when unmulched while ridges were expensive (Table 3). Mulching by incorporation was more capital intensive than surface mulch application of either fruit fibre or thrash irrespective of the seed bed preparation method. The gross revenue varied significantly $(\mathrm{P}<0.05)$ among the seed bed preparation, mulching methods and the mulch material. The highest gross revenue from Telfairia production was obtained when bed and harrowed flat seed bed preparations were surface mulched with fruit fibre. Least revenue was 
Table 1. The effect of seed bed preparations and mulching methods on the days of seed emergence (\%) and yield $\left(\mathrm{t} \mathrm{ha}^{-1}\right)$ of Telfairia Occidentalis

\begin{tabular}{|c|c|c|c|c|c|c|c|}
\hline \multirow{2}{*}{$\begin{array}{l}\text { Seed Bed } \\
\text { preparation }\end{array}$} & \multirow[t]{2}{*}{ Mulching method } & & Fruit fibre & \multicolumn{2}{|l|}{ Mulch } & Thrash & Mulch \\
\hline & & $\begin{array}{l}\text { Days for } \\
50 \% \\
\text { emergence }\end{array}$ & Leaf yield $\left(\right.$ tha $\left.^{-1}\right)$ & $\begin{array}{l}\text { Pod yield } \\
\left(\text { tha }^{-1}\right)\end{array}$ & $\begin{array}{c}\text { Days of } \\
\text { emergence } \\
(50 \%)\end{array}$ & $\begin{array}{c}\text { Leaf yield (tha } \\
{ }^{1} \text { ) }\end{array}$ & $\begin{array}{c}\text { Pod } \\
\text { yield } \\
\left(\text { tha }^{-1}\right)\end{array}$ \\
\hline \multirow[t]{4}{*}{ Minimum tillage } & Unmulched & 8.64 & 5.87 & 0.65 & 10.57 & 5.80 & 0.80 \\
\hline & Surface & 7.32 & 9.64 & 2.42 & 7.84 & 7.58 & 1.64 \\
\hline & Incorporation & 7.00 & 10.84 & 2.38 & 7.22 & 7.46 & 1.85 \\
\hline & Mean & 7.65 & 8.78 & 1.82 & 8.54 & 6.95 & 1.43 \\
\hline \multirow[t]{4}{*}{ Harrowed } & Unmulched & 8.44 & 10.86 & 1.82 & 8.28 & 6.50 & 1.28 \\
\hline & Surface & 6.84 & 18.42 & 3.56 & 7.42 & 10.48 & 2.42 \\
\hline & Incorporation & 6.04 & 20.82 & 3.34 & 7.54 & 10.46 & 2.54 \\
\hline & Mean & 7.11 & 16.70 & 2.91 & 7.75 & 9.15 & 2.08 \\
\hline \multirow[t]{4}{*}{ Bed } & Unmulched & 8.40 & 8.58 & 1.76 & 7.86 & 9.64 & 4.60 \\
\hline & Surface & 6.18 & 18.40 & 3.48 & 7.28 & 12.38 & 2.82 \\
\hline & Incorporation & 6.00 & 18.62 & 3.24 & 7.22 & 16.50 & 2.50 \\
\hline & Mean & 6.86 & 15.20 & 2.83 & 7.45 & 12.84 & 3.31 \\
\hline \multirow[t]{4}{*}{ Ridge } & Unmulched & 8.24 & 7.52 & 0.85 & 8.02 & 6.14 & 0.94 \\
\hline & Surface & 7.58 & 12.60 & 3.42 & 7.56 & 8.50 & 1.58 \\
\hline & Incorporation & 6.40 & 14.46 & 3.54 & 7.20 & 9.65 & 1.57 \\
\hline & Mean & 7.41 & 11.53 & 2.60 & 7.59 & 8.10 & 1.36 \\
\hline $\operatorname{LSD}_{0.05}$ & & 2.11 & 3.42 & 2.64 & 3.72 & 2.54 & 2.08 \\
\hline
\end{tabular}

Table 2. The effect of seed bed preparations and mulching methods on weed dry-weight, disease score and bioindicator species

\begin{tabular}{|c|c|c|c|c|c|c|c|}
\hline \multirow{2}{*}{$\begin{array}{c}\text { Seed Bed } \\
\text { Preparation }\end{array}$} & \multirow{2}{*}{$\begin{array}{l}\text { Mulching } \\
\text { method }\end{array}$} & \multicolumn{3}{|c|}{ Palm bunch fibre } & \multicolumn{3}{|c|}{ Thrash } \\
\hline & & $\begin{array}{c}\text { Weed dry } \\
\text { weight }\left(\text { tha }^{-1}\right)\end{array}$ & $\begin{array}{l}\text { Disease } \\
\text { incidence } \\
(\%) \text { score }\end{array}$ & $\begin{array}{c}\text { Bioindicator } \\
\text { species }\end{array}$ & $\begin{array}{c}\text { Weed } \\
\text { dry } \\
\text { weight } \\
\left(\text { tha }^{-1}\right)\end{array}$ & $\begin{array}{l}\text { Disease } \\
\text { incidence } \\
(\%) \text { score }\end{array}$ & $\begin{array}{c}\text { Bioindicator } \\
\text { species }\end{array}$ \\
\hline \multirow[t]{4}{*}{ Minimum tillage } & Unmulched & 3.53 & 75.42 & 3.02 & 3.46 & 76.44 & 3.20 \\
\hline & Surface & 1.25 & 62.28 & 6.40 & 2.28 & 65.40 & 6.52 \\
\hline & Incorporation & 1.35 & 60.00 & 6.45 & 2.03 & 64.82 & 6.48 \\
\hline & Mean & 2.04 & 65.90 & 5.29 & 2.59 & 68.89 & 5.40 \\
\hline \multirow[t]{4}{*}{ Harrowed Flat } & Unmulched & 1.45 & 46.58 & 4.21 & 1.68 & 51.22 & 4.02 \\
\hline & Surface & 0.76 & 16.20 & 10.54 & 1.25 & 20.40 & 8.50 \\
\hline & Incorporation & 0.62 & 18.40 & 12.62 & 1.44 & 18.44 & 10.56 \\
\hline & Mean & 0.94 & 27.06 & 9.12 & 1.46 & 30.02 & 7.69 \\
\hline \multirow[t]{4}{*}{ Bed } & Unmulched & 0.85 & 38.34 & 5.50 & 2.08 & 42.38 & 5.32 \\
\hline & Surface & 0.68 & 15.42 & 12.48 & 0.98 & 20.24 & 10.02 \\
\hline & Incorporation & 1.94 & 16.54 & 16.52 & 1.04 & 20.40 & 12.48 \\
\hline & Mean & 1.16 & 23.43 & 11.50 & 1.36 & 27.67 & 9.27 \\
\hline \multirow[t]{4}{*}{ Ridge } & Unmulched & 1.48 & 61.50 & 3.48 & 2.08 & 54.50 & 3.00 \\
\hline & Surface & 0.65 & 26.42 & 6.82 & 1.88 & 28.62 & 7.52 \\
\hline & Incorporation & 0.42 & 22.60 & 8.69 & 1.60 & 29.04 & 8.46 \\
\hline & Mean & 0.85 & 36.84 & 6.33 & 1.85 & 37.39 & 6.33 \\
\hline $\operatorname{LSD}_{0.05}$ & & 0.64 & 12.28 & 2.08 & 0.82 & 9.82 & 1.12 \\
\hline
\end{tabular}


generated in minimum tillage and ridge land preparations without mulching. The highest return on telfairia production investment was achieved when telfairia was grown on bed and harrowed flat seed bed preparations and mulched with palm fruit fibre. The minimum tillage system when mulched was superior to ridge tillage even when mulched. The residual effect to mulching significantly $(\mathrm{P}<0.05)$ enhanced the soil nutrient status and acidity (Table 4). The soil acidity was almost neutralized while sufficient quantities of some essential micro elements remained in soil after Telfairia cropping. Fruit fibre was superior to thrash on soil nutrient replenishment. The Telfairia production on unmulched soils further depleted the already infertile ultisol

Table 3. The effect of seed bed preparation and mulching methods on the cost and return $\left({\left.\mathrm{N} 000 \mathrm{th}^{-1}\right)}^{-1}\right.$ for Telfairia production in Southeastern Nigeria.

\begin{tabular}{|c|c|c|c|c|c|c|c|c|c|c|}
\hline \multirow{3}{*}{$\begin{array}{c}\text { Seed Bed } \\
\text { Preparation }\end{array}$} & \multirow{3}{*}{$\begin{array}{l}\text { Mulching } \\
\text { method }\end{array}$} & \multirow{3}{*}{$\begin{array}{c}\text { Total } \\
\text { variable cost } \\
\frac{(\mathrm{N} 000)}{\text { (fruit }} \\
\text { fibre/thrash) }\end{array}$} & \multirow{2}{*}{\multicolumn{2}{|c|}{$\frac{\text { Total yield }\left(\mathrm{t} \mathrm{ha}^{-1}\right.}{\underline{\text { /mulch }}}$}} & \multirow{2}{*}{\multicolumn{2}{|c|}{ Gross Revenue }} & \multicolumn{2}{|c|}{ Marginal gain } & \multicolumn{2}{|c|}{ Benefit cost ratio } \\
\hline & & & & & & & & & & \\
\hline & & & Fruit fibre & Thrash & Fruit fibre & Thrash & $\begin{array}{l}\text { Fruit } \\
\text { fibre }\end{array}$ & Thrash & $\begin{array}{l}\text { Fruit } \\
\text { fibre }\end{array}$ & Thrash \\
\hline \multirow{4}{*}{$\begin{array}{l}\text { Minimum } \\
\text { tillage }\end{array}$} & Unmulched & 15.24 & 6.52 & 6.66 & 45.64 & 46.62 & 30.40 & 31.88 & 2.00 & 2.10 \\
\hline & Surface & 21.42 & 12.06 & 9.22 & 84.42 & 64.54 & 62.28 & 43.08 & 2.55 & 2.83 \\
\hline & Incorporation & 25.24 & 13.22 & 9.31 & 92.04 & 65.17 & 67.30 & 39.93 & 2.67 & 1.58 \\
\hline & Mean & 20.63 & 10.60 & 8.40 & 74.03 & 58.78 & 53.33 & 38.30 & 2.40 & 2.17 \\
\hline \multirow[t]{4}{*}{ Flat } & Unmulched & 20.58 & 12.68 & 7.78 & 88.76 & 54.46 & 68.18 & 33.88 & 2.41 & 1.65 \\
\hline & Surface & 26.82 & 21.98 & 12.88 & 15386 & 90.16 & 47.04 & 68.34 & 3.31 & 2.55 \\
\hline & Incorporation & 28.64 & 24.26 & 13.02 & 169.82 & 91.14 & 141.18 & 62.50 & 4.74 & 2.18 \\
\hline & Mean & 25.35 & 19.64 & 11.23 & 137.48 & 78.59 & 85.47 & $\mathbf{5 4 . 9 0}$ & 3.49 & 2.13 \\
\hline \multirow[t]{4}{*}{ Bed } & Unmulched & 22.66 & 10.36 & 14.24 & 72.52 & 99.68 & 72.52 & 77.02 & 4.32 & 3.40 \\
\hline & Surface & 25.04 & 21.86 & 15.10 & 153.16 & 105.77 & 150.62 & 80.77 & 3.20 & 3.56 \\
\hline & Incorporation & 30.82 & 21.86 & 19.00 & 153.02 & 133.00 & 122.20 & 102.18 & 6.12 & 3.32 \\
\hline & Mean & 26.17 & 18.03 & 16.11 & 126.23 & 112.8 & 115.11 & 86.66 & 4.55 & 3.42 \\
\hline \multirow[t]{4}{*}{ Ridge } & Unmulched & 28.08 & 8.47 & 6.98 & 59.25 & 48.86 & 31.17 & 20.18 & 4.43 & 0.74 \\
\hline & Surface & 32.84 & 16.00 & 10.08 & 112.14 & 70.56 & 79.30 & 37.72 & 1.11 & 1.15 \\
\hline & Incorporation & 38.68 & 17.98 & 11.21 & 125.86 & 78.47 & 87.47 & 39.39 & 2.25 & 1.03 \\
\hline & Mean & 33.2 & 14.15 & 9.42 & 99.08 & 65.96 & 65.98 & 32.43 & 2.60 & 0.97 \\
\hline $\operatorname{LSD}_{0.05}$ & & 3.28 & 2.65 & 2.82 & 1.69 & 2.40 & 6.14 & 8.51 & 1.14 & 1.02 \\
\hline
\end{tabular}

FUTO Farm mean gate price of leaf and $\operatorname{pod}=\mathrm{N70,000}$ tha $^{-1}$

Table 4. The effect of fruit fibre and thrash (multispecies weed) on post experimental soil chemical properties in rainforest agroecology of Southern Nigeria

\begin{tabular}{|c|c|c|c|c|c|c|c|c|}
\hline Mulch & $\mathrm{N}(\%)$ & $\mathrm{OM}(\%)$ & $\mathrm{P}$ & K & $\begin{array}{c}\mathrm{Mg} \\
\mathrm{Cmol} / \mathrm{g}\end{array}$ & $\mathrm{Ca}$ & $S$ & $\begin{array}{c}\mathrm{P}^{\mathrm{H}} \\
\left(\mathrm{H}_{2} \mathrm{O}\right)\end{array}$ \\
\hline $\begin{array}{l}\text { Pre-experiment } \\
\text { Post experiment }\end{array}$ & 0.06 & 1.48 & 10.65 & 0.63 & 0.59 & 0.68 & 1.09 & 4.95 \\
\hline Palm bunch fibre & 0.86 & 2.84 & 9.85 & 0.98 & 0.89 & 1.34 & 2.89 & 5.58 \\
\hline Thrash (multispecies) & 0.76 & 2.98 & 9.87 & 0.94 & 0.87 & 0.98 & 2.70 & 5.56 \\
\hline Unmulched & 0.06 & 1.26 & 5.16 & 0.60 & 0.53 & 0.84 & 1.80 & 4.29 \\
\hline $\operatorname{LSD}_{0.05}$ & 0.22 & 1.08 & 1.94 & 0.16 & 0.26 & 0.20 & 0.47 & 1.02 \\
\hline
\end{tabular}




\section{DISCUSSION}

Seed bed preparation, as a post clearing operation in vegetable production, is a deliberate disturbance of the soil to modify its structure for favourable root environment (Osuji, 1990). This delicate management of the ultisol of low fertility in Southeastern Nigeria agroecology is crucial to the soil resource base, its conservation and sustainable crop yields (Ojeniyi and Adekayode, 1999, Onweremadu, et al., 2007). However appropriate seed bed preparation is dependent on available implements, soil type and scale of production (spade/hoes for smallholder and plough for commercial growers). The limitations (Ojeniyi, 1993) of continuous land preparations in crop production including Telfairia in the tropical ultisol is redeemable by mulching (Ibeawuchi and Obiefuna, 2009). Thus the productivity of Telfairia in the traditional minimum tillage and harrowed flat, bed and ridge in the conventional (commercial) tillage systems (Osuji 1990) has been remarkably enhanced (Asoegwu, 1987) by mulching with fruit fibre which is rich in nitrogen $(\mathrm{N})$, phosphorus $(\mathrm{P})$, potassium $(\mathrm{K})$ and calcium $(\mathrm{Ca})$ (Ibewauchi and Obiefuna, 2009) and to some extent, by thrash (Lal, 1986, Awodun and Ojeniyi, 1999). The improved productivity of Telfairia when the soil is tilled, harrowed and mulched was probably due to improved soil physic-chemical properties including nutrients availability (Opara-Nadi and Lal, 1987, Ohiri, 1995) water storage (Osuji and Babalola, 1982) and soil biological health (Swift et al., 2008). Except for the ridge, mulched minimum tillage, harrowed flat and seed bed preparations are cost effective for sustainable Telfairia production in the rainforest agroecology of Southeastern Nigeria.

\section{CONCLUSION}

Seed bed preparation is a repetitive agronomic operation which eventually results in poor ultisol fertility. For smallholder Telfairia growers, minimum tillage mulched with fruit fibre at $5 \mathrm{t} \mathrm{ha}^{-1}$ is advocated. For commercial growers, bed and the harrowed flat seed bed preparations mulched by surface and/ or soil incorporated with fruit fibre are cost effective and environmentally friendly. Palm fruit fibre and multispecies thrash are suitable for Telfairia production enterprise in the rainforest agroecology of Southeastern Nigeria.

\section{REFERENCES}

Adekoya, A. and Ojeniyi, S.O. (2002). Evaluation of tomato growth and soil properties under methods of seedling bed preparations in an ultisol in the rainforest of Southeastern Nigeria, Soil and Tillage Research 64:274 279.
Aiyelaagbe, I.O.O, (2011). Nigerian horticulture: facing the challenges of human health and agricultural productivity. A key note address at the $29^{\text {th }}$ Annual Conference of Horticultural Society of Nigeria (HORTSON) held at Markudi 24 - 29 July, 2011.

Akobundu, E.N.T. Obiefuna, J.C. and Meregini, H.O. (1992). A survey of horticultural crops of economic importance, food preparations and home gardens in Southeastern Nigeria. United Nations University Publication, Nairobi Kemga 92pp.

Akoroda, M.O. (1990). Ethno-botany of Telfairia occidentalis Curcubitacea, among the Igbos of Nigeria. Econ. Bok.44 (1) 29-39.

Akwuowo, E.U, Basey - Ndon, B.A, and Etuk. B.U. (2000). Minerals and anti-nutrients in fluted pumpkin (Telfairia occidentalis). Food Chemistry 70:235-240.

Aletor O., Oshodi, A.A., Ipinimolu, K. (2002). Chemical composition of common leaf vegetable and functional properties of their leaf protein concentrates. Food Chemistry 78: 63-68.

Asoegwu, S.N. (1987). Comparison of tillage systems for the production of Egusi melon and okra in Eastern Nigeria. Crop Research 27: 27-90.

Awodun M.A. and Ojeniyi S.O. (1999). Effect of weed mulch on nutrient content of the soil and grain yield of maize. Proceedings of $25^{\text {th }}$ Annual Conference of Soil Science Society of Nigeria p.116 - 119 .

Ibeawuchi I.I. and Obiefuna J.C. (2009). Productivity of some organic mulch materials on Xanthosoma sagittifolium and biofertility indicators (in press).

Lal. R. (1986). Soil surface management in the tropics in the intensive land use for high and sustained production. Advances in Soil Science 5, 1-109.

Ohiri, A.C. (1995). Soil physical and chemical conditions favourable for yam growth and tuber development in Nigeria. African Soils 28:231 - 242 .

Ojeniyi, S.O. 1990. Effect of bush clearing and tillage methods on soil physical and chemical property of humid tropical ultisol. Soil and Tillage Research 15, 269-277.

Ojeniyi, S.O. (1993). Nutrient availability and maize yield under reduced tillage practices. Soil Tillage Research 26, 89 - 92.

Ojeniyi, S.O. and Adekayode, F.O. (1999). Soil condition and cowpea and maize yield produced by tillage method in the rain forest zone of Nigeria. Soil Tillage Research 51, $161-164$ 
Onweremadu, E.U, Eshett, E.T, Osuji G.E, Unamba - Opara I, Obiefuna J.C. and Onwuliri C.O.E. (2007). Anisotropy of adaphic properties in slope soil of university farm in Owerri Southeastern Nigeria. Journal of American Science, 3(4): 52 - 61.

Opara-Nadi, O.A and Lal, R. (1987). Effect of land clearing and tillage methods on soil properties and maize good growth. Field Crops Research 15, 193 -206.

Osuji, G.E. (1990). Tillage and mulching effects on seed zone, soil environment and cowpea seedling growth in the humid tropics. Soil Use and Management 6, $152-156$

Osuji, G.E and Babalola, A.O. (1982). Tillage practices on a tropical soil. Journal of Environmental Management 14, 343 - 348.

Schippers, R.R. (2000). African indigenous vegetables. An overview of the cultivated species. Calam, UK. National Resources Institute ACP - E.U. Technical Centre for Agricultural and Rural Cooperation pp 66 73

Swift, M.J, David, E.B, Fatima M.S.M. and Huising E.J. (2008). The inventory of soil biological diversity; Concepts and general guidelines. In Fatima, M.S.M, Huising E.J. and David, E.B (eds). A handbook of tropical soil biology, sampling and characteristics of below-ground biodiversity. Earthscam Publishing, London p $1-15$.

Uguru, M.I. Olagide, J.E. Ahumana, E.O and Ezeanyika, L.U.S. (2011). Comparative effects of the leaves of Veanonia amygdalina and Telfairia occidentalis incorporated diets on the lipid profile of rats. African Journ. Biochem. Research 5(1) $28-32$. 